\title{
STRATEGI KAPABILIAS RELASIONAL BAGI LEMBAGA KESEJAHTERAAN SOSIAL DI KABUPATEN GARUT: PENGUATAN ASPEK KOLABORASI DAN KEMITRAAN LEMBAGA
}

\author{
Enung Huripah \\ Politeknik Kesejahteraan Sosial Bandung, hurip@hotmail.co.id \\ Ramli \\ Politeknik Kesejahteraan Sosial Bandung, ramli@yahoo.com \\ Endah Dwi Winarni \\ Politeknik Kesejahteraan Sosial Bandung, endah_dwiwinarni@yahoo.co.id
}

\begin{abstract}
One of important problems in organizing social welfare for People with Social Welfare Issues (PMKS) in Indonesia is the governance of Social Welfare Institutions (LKS). Indeed, LKS is a part of the Social Welfare Resources (PSKS) in Indonesia, so it is called one of the spearheads for social welfare implementation. Unfortunately, LKS tend to be problematic both internally and externally. On the other hand, the Indonesian government also encourages LKS to be accredited. Thus, this study chooses the governance of LKS in Indonesia as a theme to study. In detail, this study discusses a strategy to strengthen LKS governance capacity in collaboration and partnership aspects. These two aspects are aligned with one of the priorities of the Indonesian government for LKS, namely network and coordination improvement in social welfare implementation. This study argues the proper strategy in strengthening the LKS governance capacity in collaboration and partnership aspects is the relational capability strategy. This study is a case study research with a qualitative approach on LKS in Garut Regency.
\end{abstract}

\section{Keywords:}

PMKS; LKS; Institutional Governance Capacity; Collaboration and Partnership

\begin{abstract}
Abstrak
Salah satu isu penting dalam penyelenggaraan kesejahteraan sosial bagi Penyandang Masalah Kesejahteraan Sosial (PMKS) di Indonesia adalah tata kelola Lembaga Kesejahteraan Sosial (LKS). Memang, LKS merupakan bagian dari Potensi dan Sumber Kesejahteraan Sosial (PSKS) di Indonesia, sehingga disebut salah satu ujung tombak dalam penyelenggaraan kesejahteraan sosial. Sayangnya, LKS cenderung bermasalah secara internal maupun eksternal. Di sisi lain, pihak pemerintah Indonesia pun gencar mendorong LKS-LKS untuk terakreditasi. Maka, penelitian ini memilih tema tata kelola LKS di Indonesia. Secara terperinci, penelitian ini membahas strategi penguatan kapasitas tata kelola LKS pada aspek kolaborasi dan kemitraan. Dua aspek tersebut selaras dengan prioritas pemerintah Indonesia terhadap LKS kini, yaitu meningkatkan jejaring dan koordinasi dalam penyelenggaraan kesejahteraan sosial. Penelitian ini berargumen strategi yang tepat dalam memperkuat
\end{abstract}


kapasitas tata kelola LKS pada aspek kolaborasi dan kemitraan adalah strategi kapabilitas relasional. Penelitian ini merupakan studi kasus dengan pendekatan kualitatif pada LKS-LKS di Kabupaten Garut.

\section{Kata Kunci:}

PMKS; LKS; Kapasitas Tata Kelola Lembaga; Kolaborasi dan Kemitraan

\section{PENDAHULUAN}

Tata kelola Lembaga

Kesejahteraan Sosial (LKS) ${ }^{1}$ di Indonesia menghadapi beberapa masalah. Sugiyanto (2019) menjelaskan masalah tersebut terdiri dari masalah internal dan eksternal. Masalah internal yang dialami seperti manajemen LKS umumnya tradisional dan tertutup, belum mandiri dalam beroperasi, aset keluarga tercampur aduk dengan aset lembaga, serta sarana dan prasarana belum memadai. Kemudian, masalah eksternal yang dialami seperti sebaran LKS belum merata di daerah-daerah, pembinaan oleh dinas sosial belum merata bagi LKS-LKS di daerah, dan tuntutan pihak eksternal yang sulit dipenuhi. Sugiyanto (2019) pun menjelaskan LKS di Indonesia patut segera berbenah dalam hal regulasi, tata kelola organisasi, dan sumber daya manusia, sehingga dapat mendukung penyelenggaraan kesejahteraan sosial bagi PMKS secara signifikan.

Di sisi lain, pemerintah Indonesia sedang gencar-gencarnya mendorong LKS-LKS untuk diakreditasi. Hal ini demi

\footnotetext{
${ }^{1}$ Merujuk Permensos RI 184/2011, LKS adalah bagian dari Potensi dan Sumber Kesejahteraan Sosial (PSKS) di Indonesia. LKS dibentuk guna berperan dalam menjaga, menciptakan, mendukung, dan memperkuat penyelenggaraan
}

meningkatkan profesionalitas kerja LKS dalam penyelenggaraan kesejahteraan sosial (Kemensos, 2019). Memang, secara umum, persentase LKS-LKS yang sudah diakreditasi meningkat dari tahun ke tahun. Pada 2018, peningkatannya signifikan dibandingkan tahun sebelumnya dari 3,79\% menjadi $7,18 \%$ (Kemensos, 2019). Namun, sayangnya, jumlah persentase pada 2018 tersebut belum mencapai target sebesar $11,60 \%$ (Kemensos, 2019). Bahkan, jika merujuk pada target 2019 sebesar 17,30\%, capaiannya baru 41,50\% (Kemensos, 2019). Artinya, pemerintah memerlukan upaya yang lebih masif untuk mencapai target pada 2019. Pemerintah berharap mampu meningkatkan persentase LKS yang sudah diakreditasi demi penyelenggaraan kesejahteraan sosial bagi PMKS.

Berdasarkan isu di atas, penelitian ini akan membahas tentang strategi penguatan kapasitas aspek-aspek tata kelola LKS dengan fokus pada aspek kolaborasi dan kemitraan. Konsep tata

kesejahteraan sosial. Secara terperinci, LKS merupakan salah satu ujung tombak dalam penyelenggaraan kesejahteraan sosial bagi Penyandang Masalah Kesejahteraan Sosial (PMKS) di Indonesia 
kelola lembaga yang digunakan dalam penelitian ini merujuk Bell et al. (2015). Ia membagi tata kelola lembaga menjadi lima aspek, yaitu sumber daya, infrastruktur, pengetahuan dan keterampilan, kultur, serta kolaborasi dan kemitraan. Alasan pembatasan hanya pada aspek kolaborasi dan kemitraan adalah mengikuti prioritas Kemensos (2019) bagi LKS-LKS. Menurut Kemensos (2019), LKS kini wajib meningkatkan jejaring dan koordinasi dalam penyelenggaraan kesejahteraan sosial. Bahkan, hal ini termasuk sebagai parameter yang ditetapkan guna mengukur partisipasi aktif PSKS kelembagaan, termasuk LKS, dalam penyelenggaraan kesejahteraan sosial.

Penelitian tentang strategi penguatan kapasitas aspek-aspek tata kelola LKS dengan fokus pada aspek kolaborasi dan kemitraan belum banyak dilakukan. Di Indonesia, umumnya penelitian-penelitian yang ada membahas tentang latar belakang pembentukan LKS (Sitepu, 2011), implementasi programprogram LKS (Marbun et al., 2012; Kuswanda \& Sundayani, 2013; Diyanayati, 2014), dan evaluasi kapasitas tata kelola LKS (Sugiyanto, 2019). Sementara itu, di negara-negara lain, umumnya penelitian-penelitian yang ada membahas tentang strategi untuk meningkatkan kapasitas SDM (Maynard, 2010; Austin et al., 2011; McPherson \& Abell, 2020; Turpin et al., 2020) serta strategi untuk memperkuat tata kelola finansial (Patras \& Klest, 2011; Xie et al., 2014; Williams-Gray, 2016).

Penelitian ini berargumen strategi yang tepat dalam memperkuat kapasitas tata kelola LKS pada aspek kolaborasi dan kemitraan adalah strategi kapabilitas relasional. Dalam konteks penelitian ini, definisi strategi kapabilitas relasional adalah rancangan aksi untuk memperkuat kapasitas tata kelola lembaga dalam membangun hubungan berkelanjutan antar pihak internal dan dengan pihak eksternal. Secara terperinci, hubungan-hubungan yang dimaksud terdiri dari kolaborasi internal lembaga, kemitraan eksternal lembaga, partisipasi dan kelekatan komunitas atau organisasi (seperti komunitas sosial, komunitas akademis, atau organisasi bisnis), serta partisipasi dan kelekatan kelompok masyarakat (seperti warga sekitar, kelompok pemuda, atau keluarga) (Renouard, 2011; Giraud et al., 2013; Bell et al., 2015).

\section{METODE}

Penelitian ini merupakan studi kasus dengan pendekatan kualitatif pada LKS-LKS di Kabupaten Garut. Mulanya, penelitian ini membahas isu tata kelola LKS dalam penyelenggaraan kesejahteraan sosial bagi PMKS di Indonesia. Kemudian, penelitian ini menganalisis isu tersebut demi mencapai tujuan penelitian berupa mempromosikan strategi penguatan kapasitas tata kelola LKS pada aspek kolaborasi dan kemitraan, yaitu strategi kapabilitas relasional. 
Teknik pengumpulan data yang memungkinkan untuk hal tersebut adalah teknik naturalistik-interpretatif, khususnya dengan wawancara mendalam atau FGD bersama informan. Adapun validasi data memakai strategi triangulasi data dan pengolahannya menggunakan teknik pengolahan kualitatif.

Alasan memilih Kabupaten Garut adalah jumlah warganya yang tergolong sebagai PMKS cenderung tinggi, yaitu sebanyak 1.316.818 jiwa pada 2019, dengan jumlah LKS di daerah tersebut yang selalu bertambah setiap tahunnya, yaitu 79 kelompok pada 2017, 125 kelompok pada 2018, dan 127 kelompok pada 2019 (Dinsos Jabar, 2018; 2019; 2020). Selain itu, Dinas Sosial Jawa Barat (Dinsos Jabar) juga telah mendorong adanya kolaborasi dan kemitraan penyelenggaraan kesejahteraan sosial bagi PMKS di Kabupaten Garut melalui forum Corporate Social Responsibility Kesejahteraan Sosial (forum CSR Kesos) (Pikiran Rakyat, 2019).

Informan penelitian ini diseleksi secara purposive. Artinya, informan dipilih karena kesesuaian karakteristik mereka dengan konteks penelitian (Creswell, 2003). Informan dibagi menjadi dua kategori, yaitu informan utama dan pendukung. Ciri informan utama penelitian ini adalah para pengurus dan peserta LKS-LKS di Kabupaten Garut. Kemudian, ciri informan pendukungnya adalah pemangku kepentingan LKS-LKS di Kabupaten Garut, seperti pihak pemerintah, komunitas, ataupun kelompok masyarakat.

LKS-LKS di Kabupaten Garut yang terlibat dalam penelitian ini berjumlah lima lembaga, yaitu RPSTW Garut, LKSA Al-Amin, Yayasan Sosial PASI Garut Ibu Aledja Anggapraja, Yayasan Bina Grahita Leles Garut, dan Yayasan Nurilahie Assani. Alasan memilih kelima lembaga tersebut karena merepresentasikan sasaran PMKS yang berbeda-beda, yaitu lansia, anak, anak dengan disabilitas, dan rehabilitasi mental.

\section{HASIL PENELITIAN}

Pada bagian Hasil Penelitian ini, akan dipaparkan soal kondisi LKS di Kabupaten Garut. Bagian ini kemudian akan terdiri dari tiga hal, yaitu Gambaran Umum LKS di Kabupaten Garut, Penyelenggaraan LKS di Kabupaten Garut, dan Tata Kelola LKS di Kabupaten Garut Secara Umum

\section{Gambaran Umum LKS di Kabupaten Garut}

Pada subbab ini, akan dipaparkan tentang beberapa contoh LKS di Kabupaten Garut yang menjadi objek atau studi kasus penelitian ini. Pemaparan ini menjadi penting sebagai gambaran konteks menyeluruh dari tempat yang dijadikan untuk studi kasus. Kemudian, setelah itu, akan dijelaskan pula kebijakan atau program-program pemerintah Kabupaten Garut bagi LKS demi 
memperlengkap aspek kontekstual dalam penelitian ini.

Beberapa LKS yang dimaksud terdiri dari dua jenis, yaitu LKS pemerintah dan LKS swasta. LKS pemerintah dalam penelitian ini yang dimaksud adalah Rumah Perlindungan Sosial Tresna Werdha (RPSTW) Kabupaten Garut yang memfokuskan diri pada penyelenggaraan kesejahteraan sosial lansia, Lembaga Kesejahteraan Sosial Anak (LKSA) Al-Amin yang memfokuskan diri pada penyelenggaraan kesejahteraan sosial anak, Yayasan Sosial PASI Garut Ibu Aledja Anggapraja yang memfokuskan diri pada penyelenggaraan kesejahteraan sosial anak, Yayasan Bina Grahita Leles Garut yang memfokuskan diri pada penyelenggaraan kesejahteraan sosial anak disabilitas atau berupa sekolah luar biasa (SLB), dan Yayasan Nurilahie Asssani yang memfokuskan diri pada yayasan rehabilitasi mental.

Peran dari RPSTW Garut dapat digambarkan dengan visi dan misinya. Visi dari RPSTW Garut adalah "Rumah Perlindungan Sosial Tresna Werdha Garut sebagai subunit terbaik dalam pelayanan lanjut usia di Indonesia". Untuk itu, misi yang ingin dilakukan dan dicapai demi pencapaian visi tersebut adalah a) mewujudkan lanjut usia yang memiliki harkat, martabat, dan kualitas kesehatan yang prima; b) mengembangkan sistem dan mekanisme layanan lanjut usia; c) menciptakan sumber daya manusia pelaksana fungsi layanan lanjut usia yang andal; d) mewujudkan sarana dan prasarana pendukung fungsi layanan lanjut usia yang memadai; dan e) mengembangkan jejaring kerja dalam meningkatkan peran dan fungsi institusi.

LKSA Al Amin memberikan pelayanan kesejahteraan sosial anak dalam bentuk berupa pengasuhan, pendidikan, pemenuhan kebutuhan sandang, pangan, papan, dan kesehatan pada semua jenjang pendidikan dari SD sampai Perguruan Tinggi. Jumlah anak asuh yang ada sekarang adalah sebanyak 55 orang, terdiri dari 29 laki-laki dan 26 perempuan. Kegiatan pokok yang selalu dilakukan adalah pendidikan formal di sekolah umum dan pendidikan nonformal seperti keterampilan dan kegiatan kerohanian. Kemudian, usaha produktif yang setiap waktu dilakukan karena sesuai dengan potensi lahan di sekitar yang dimiliki adalah usaha budidaya ikan lele.

Yayasan sosial PASI Garut Ibu Aledja Anggapraja merawat dan mendidik anak-anak yatim piatu serta anak-anak terlantar. Selain itu, yayasan ini pun memenuhi kebutuhan anak-anak yang dirawatnya mulai dari makanan hingga sekolahnya. Tujuan didirikannya Yayasan Sosial PASI Garut Ibu Aledja Anggapraja: a) turut serta menyukseskan program pemerintah dalam rangka mengentaskan kemiskinan dan meningkatkan kecerdasan, b) menyalurkan infaq, zakat, sadaqah, dan amal jariyah lain bagi mereka yang telah mencapai pada batas ketentuan, 
dan c) memperbaiki taraf hidup mereka yang kurang beruntung.

\section{Penyelenggaraan LKS di Kabupaten Garut}

Penyelenggaraan kesejahteraan sosial di Kabupaten Garut dilaksanakan oleh beberapa pihak, di antaranya Dinas Sosial, Tenaga Kerja, dan Transmigrasi dengan penumbuhan dan pengembangan Kube, bantuan stimulan rumah tidak layak huni, dan Program Keluarga Harapan, Dinas Kesehatan dengan jaminan kesehatan masyarakat, program sanitasi, dan peningkatan gizi, Dinas Pendidikan dengan program pendidikan anak usia dini, wajib belajar sembilan tahun (BOS), dan bantuan siswa miskin. Dinas Sosial, Tenaga Kerja, dan Transmigrasi Kabupaten Garut yang merupakan representasi Kementerian Sosial di daerah memiliki dua bidang yang berkaitan dengan program Kementerian Sosial, yaitu Bidang Pemberdayaan dan Pengembangan Sosial (Seksi Pemberdayaan Sosial, Pengembangan Sosial, dan Pengembangan Partisipasi Sosial) dan Bidang Bantuan Jaminan dan Rehabilitasi Sosial (Seksi Bantuan dan Perlindungan Sosial, Pelayanan Sosial, dan Rehabilitasi Sosial).

Dua bidang tersebutlah yang kemudian bertanggung jawab terhadap eksistensi dan pengembangan LKS di Kabupaten Garut. Kini, di Kabupaten Garut, jumlah warganya yang tergolong sebagai PMKS cenderung tinggi, yaitu sebanyak 1.316.818 jiwa, dengan jumlah
LKS di daerah tersebut yang selalu bertambah setiap tahunnya: 2017 sebanyak 79 kelompok, 2018 sebanyak 127 kelompok, dan 2019 sebanyak 129 kelompok (Dinsos Jabar, 2018; 2019; 2020). Adapun tugas-tugas dua bidang tersebut yang menyangkut pengembangan LKS di Kabupaten Garut adalah sebagai berikut:

a. Melakukan aktivtias perencanaan, pelaksanaan, monitoring atau pemantauan, evaluasi, dan pelaporan fasilitasi kesejahteraan sosial melalui LKS dan/atau PMKS di luar balai/lembaga/panti;

b. Melakukan aktivtias perencanaan, pelaksanaan, monitoring atau pemantauan, evaluasi, dan pelaporan pemberdayaan sosial keluarga dan komunitas adat serta pemberdayaan dan pendayagunaan kelembagaan sosial;

c. Melakukan aktivtias perencanaan, pelaksanaan, monitoring atau pemantauan, evaluasi, dan pelaporan bimbingan teknis, bantuan, dan pemeliharaan taraf kesejahteraan sosial;

d. Melakukan aktivtias perencanaan, pelaksanaan, monitoring atau pemantauan, evaluasi, dan pelaporan pedoman penyelenggaraan bantuan peningkatan kapasitas kelembagaan sosial; 
Tata Kelola LKS di Kabupaten Garut Secara Umum

Tata kelola lembaga LKS dalam penelitian ini didefinisikan sebagai segala sumber daya internal dan eksternal, serta kondisi lain yang memengaruhi kemampuan lembaga, yang bermanfaat guna mencapai tujuan (Bell et al., 2015)dalam konteks ini, berarti tujuannya adalah melaksanakan penyelenggaraan kesejahteraan sosial bagi PMKS. Tata kelola lembaga LKS tersebut kemudian terdiri dari sumber daya, infrastruktur, pengetahuan dan keterampilan, kultur, serta kolaborasi dan kemitraan.

Aspek pertama adalah sumber daya LKS di Kabupaten Garut. Dalam hal ini, sumber daya, sesuai definisi Bell di atas, maksudnya adalah sesuatu yang dimiliki oleh LKS bersangkutan yang bersifat materiel dan konkret untuk membantu proses pelayanan sehari-hari, seperti sarana-prasarana yang ada di LKS tersebut, alat-alat kerja, alat-alat teknologi, ataupun dana yang dimiliki. Secara umum, sarana dan prasarana baik di LKS pemerintah dan swasta sudah layak untuk pelayanan sehari-hari, seperti tersedia kantor, aula untuk berkumpul, ruang perawatan medis, lahan mandiri, dan lainlain. Alat kerja juga sudah layak untuk keperluan pihak pengurus.

Alat teknologi diutamakan untuk pemenuhan kesejahteraan pasien, seperti penyediaan teknologi medis di yayasan rehabilitasi dan alat bantu dengar atau kursi roda bagi lansia. Sumber dana bermacam-macam, ada yang dari alokasi APBD, BOS, swadaya pengurus, donasi masyarakat (tidak mengikat), ataupun pasien. Ini semua bergantung dari jenis LKS terkait. Pengeluarannya dimanfaatkan seefektif mungkin karena adanya keterbatasan.

"Dana sumbernya ada beberapa, seperti dari donatur, dari pemerintah, dan sekali-kali dari bupati yang sifatnya bantuan insidental. Dana rutin ada dari Yayasan Dharmais jumlahnya sekitar Rp1.850.000. [...] Kendala paling dana dari sumber lain saja, jadi harapannya bisa dapat juga dukungan dari berbagai macam pihak. Ini supaya kami bisa merawat fasilitas sarana-prasarana yang sudah rusak atau untuk memastikan operasional LKS bisa berjalan makin lancar saja." Kutipan wawancara mendalam dengan Ibu Darsih Sudarsih, Kepala Asrama Yayasan Sosial PASI Garut Ibu Aledja Anggapraja

Aspek kedua adalah infrastruktur LKS di Kabupaten Garut. Dalam hal ini, infrastruktur, sesuai definisi Bell di atas, maksudnya adalah sesuatu yang menjadi acuan bagi LKS bersangkutan untuk melakukan pelayanan kesejahteraan sosial, seperti peraturan umum, prosedur kerja, struktur kepengurusan, ataupun kurikulum program-program pelayanan kesejahteraan sosial. LKS umumnya 
sudah mempunyai peraturan umum, prosedur kerja, struktur kepengurusan, ataupun kurikulum program-program pelayanan kesejahteraan sosial.

Penentuan infrastruktur tersebut bermacam-macam bergantung pada jenis LKS. Jika LKS pemerintah, infrastruktur tersebut menyesuaikan aturan-aturan pemerintah yang berlaku dan diawasi oleh dinas sosial. Jika LKS swasta, umumnya juga mengacu kurikulum yang diberikan dinas. Namun, penentuan spesifiknya dilakukan musyawarah. Secara umum, implementasi peraturan, prosedur kerja, ataupun kurikulum program tidak begitu ketat baik bagi LKS pemerintah ataupun swasta.

"Ada, walaupun tidak ketat (peraturan umum, prosedur kerja, struktur kepengurusan, ataupun kurikulum program-program). [...] Ditentukan secara musyawarah mufakat, mengacu pada kurikulim SLB dari Diknas. [...] kendala dan harapannya adalah relawan yang profesional, dan penguatan kapasitas." Kutipan wawancara mendalam dengan Ibu Umi Neni Haryani, Ketua Yayasan Bina Grahita Leles Garut

Aspek ketiga adalah pengetahuan dan keterampilan di LKS Kabupaten Garut. Dalam hal ini, pengetahuan dan keterampilan, sesuai definisi Bell di atas, maksudnya adalah pengetahuan kognitif serta keterampilan teknis yang dimiliki oleh pihak pengurus LKS bersangkutan yang berguna bagi peningkatan pelayanan kesejahteraan sosial. Latar belakang pengurus dan relawan umumnya bervariasi, siapa pun dapat menjadi pengurus, tidak ada persyaratan khusus, seperti ada yang SMA, SMK, ataupun sarjana. Sudah tentu tugas utama pengurus-pengurus LKS adalah mengelola keberlangsungan yayasan, sesuai dengan struktur kepengurusan yang diatur. Untuk pengurus teknis, seperti perawat dan guruguru SLB ataupun pihak medis, diutamakan telah memiliki latar pendidikan yang serupa dan sudah mengikuti pelatihan tertentu yang disediakan oleh dinas ataupun swasta

"Di sini ada bermacam-macam, ada S1: 5 orang, D3: 1 orang, D2: 1 orang, SMA: 8 orang, SMP: 7 orang, dan SD: 5 orang. [...] Pokoknya syarat-syaratnya disesuaikan dengan kompetensi dan kebutuhan LKS ini. [...] Kalau soal pengelolaan SDM, kendalanya adalah kurangnya peningkatan kompentesi bagi SDM di LKS. Jadi, semoga banya program pelatihan untuk peningkatan kompetensi." Kutipan wawancara mendalam dengan Ibu Heni, Pekerja Sosial di RPSTW Garut

Aspek terakhir dalam hal tata kelola lembaga secara umum atau aspek keempat tata kelola LKS di Kabupaten Garut adalah kultur LKS di Kabupaten Garut. Dalam hal ini, kultur, sesuai dengan 
definisi Bell di atas, maksudnya adalah nilai dan norma yang diterapkan di LKS bersangkutan yang dapat membantu meningkatkan proses pelayanan kesejahteraan sosial. Secara umum, setiap LKS sudah memiliki visi-misi dan nilainilai yang ditetapkan dengan mengacu aturan-aturan dinas terkait serta jenis LKS terkait.

Sebagai contoh, jika jenis LKS SLB, semangatnya adalah nilai toleransi dan inklusif. Konflik yang terjadi antar pengurus atau penghuni merupakan hal yang negatif dan dapat menciptakan kesenjangan dan akan memperburuk nilai inklusivitas.

"Iya, ada. LKS ini punya visi dan misi. Visinya adalah satpel juara dalam pelayanan lanjut usia dan pemeliharaan makam pahlawan di indonesia tahun 2023. Kalau misinya itu 1. mewujudkan lanjut usia yang memiliki harkat, martabat, dan kualitas kesehatan yang juara, 2 . mengembangkan sistem dan mekanisme layanan, 3. menciptakan sumber daya manusai pelaksana funggsi layanan yang memadai, dan 4. mengembangkan jejaring kerja dalam meningkatkan peran dan fungsi institusi. [...] Kalau ada konflik, kami biasanya melaksanakan CC, bimbingan individu, dan rapat semua pegawai." Kutipan wawancara mendalam dengan Ibu Heni, Pekerja Sosial di RPSTW Garut

\section{PEMBAHASAN}

Pada bagian Pembahasan ini, akan dipaparkan tentang tiga hal untuk mendukung argumen penelitian. Pertama, akan dipaparkan analisis tata kelola LKS di Kabupaten Garut pada aspek kolaborasi dan kemitraan, analisis masalah tata kelola LKS di Kabupaten Garut pada aspek kolaborasi dan kemitraan, serta terakhir memaparkan strategi kapabilitas relasional yang merupayakan upaya untuk memperkuat tata kelola LKS di Kabupaten Garut pada aspek kolaborasi dan kemitraan.

\section{Analisis Tata Kelola LKS di Kabupaten Garut pada Aspek Kolaborasi dan Kemitraan}

Tata kelola LKS di Kabupaten Garut pada aspek kolaborasi dan kemitraan mengartikan jalinan hubungan internal dan eksternal yang dimiliki oleh LKS bersangkutan demi peningkatan pelayanan kesejahteraan sosial. Jalinan hubungan yang produktif tersbebut melibatkan tiga nilai utama, yaitu membangun kepercayaan, mencari umpan balik, dan secara aktif berkolaborasi menuju tujuan bersama secara berkelanjutan (Bell et al., 2015).

Aspek ini menampilkan proses, dinamika, dan produk kerja sama yang ada dan dihasilkan antara pihak-pihak terkait. Sesuai dengan pemahaman Bell et al. (2015) di atas, ada empat subaspek kolaborasi dan kemitraan tata kelola LKS 
di Kabupaten Garut yang akan dibahas, yaitu kolaborasi internal lembaga, kemitraan eksternal lembaga, partisipasi dan kelekatan komunitas atau organisasi, serta partisipasi dan kelekatan kelompok masyarakat.

Pada subaspek pertama, kolaborasi internal LKS di Kabupaten Garut, dapat dilihat dari tingkat kepercayaan, kerja sama, dan keterlibatan seluruh penghuni LKS (pengurus dan klien) dalam kegiatan keseharian. Secara umum bagi LKS di Kabupaten Garut, hubungan antar pengurus-pengurus, pengurus-penghuni, dan sesama penghuni umumnya baik dan tingkat kepercayaan tinggi. Memang, konflik beberapa kali terjadi antar penghuni, misalnya apabila PMKS tersebut adalah anak-anak atau lansia, tetapi selalu dupayakan untuk diselesaikan secara musyawarah dan kekeluargaan. Begitu pula apabila ada PMKS yang melanggar aturan, penyelesainnya dilakukan secara internal saja dengan nilai kekeluargaan, kecuali apabila PMKS tersebut sudah melewati batas.

Salah satu contohnya adalah PMKS yang berupa anak-anak. Di salah satu LKS yang mengurusi anak-anak, apabila anak-anak tersebut sudah melewati batas, akan dipanggil keluarga atau walinya dan apabila tidak dapat dinasihati lagi akan dikembalikan ke keluarga atau wali tersebut. Di setiap LKS di Kabupaten Garut pun kegiatan untuk bonding dilakukan demi meningkatkan kolaborasi internal, seperi dibuatkan games atau group work, arisan, pengajian, guyub rutin, atau sesekali tamasya bareng.

Keterlibatan penghuni di LKS selalu diupayakan, dengan cara menuruti jadwal yang sudah ditepati dan adanya pemantauan dan evaluasi bagi penghuni agar terlibat dalam kegiatan. Adapun pengurus-pengurus mengakui bahwa bekerja sama dan saling percaya dengan tim itu sangat penting demi penyelengaraan kesejahteraan sosial yang maksimal di LKS, dan hal ini memang sudah bagian dari profesionalitas.

"Ya... disesuaikan saja dengan jadwal yang sudah ditetapkan di LKS. Selain itu, ada juga monitoring dan evaluasi (dalam memastikan keterlibatan penghuni LKS). [...] Pokoknya kami di sini selalu berpikir positif antar sesama yang di sini. Kalau dengan PMKS, di kegiatan itu ada group work dan konseling juga. [...] Tidak ada kendala antar pengurus di sini. Kalau dengan klien atau PMKS, kendalanya adalah harus memenuhi keinginan dan harapan mereka, kadang sulit-sulit untuk dipenuhi, tapi itu sudah tugas jadi harus diselesaikan dengan gimana pun caranya yang baik. Sebagai contoh, kalau di masa sekarang karena pandemi corona, kami harus memenuhi keinginan lansia kayak misalnya mereka yang ingin ketemu keluarga. Itu susah dilakukan demi kesehatan juga, tapi ya... dipikirkan saja caranya yang baik dan sesuai protokol bagaimana." Kutipan 
wawancara mendalam dengan Ibu Heni, Pekerja Sosial di RPSTW Garut

Subaspek berikutnya, kemitraan LKS di Kabupaten Garut, dapat dilihat dari tingkat kepercayaan dari mitra dan bentuk kerja sama dengan mitra. Dalam hal ini, mitra yang dimaksud semisal lembaga sejenis lainnya ataupun pihak pemerintah. Secara umum bagi LKS di Kabupaten Garut, baik LKS pemerintah dan swasta saling bekerja sama dengan LKS lain yang sejenis. Bentuk kerja samanya seperti saling bertukar informasi, saling memenuhi alat-alat teknologi untuk kepentingan penyelenggaraan kesejahteraan sosial (seperti alat medis untuk LKS yang memang fokus pada kesehatan PMKS), dan saling memenuhi pengurus-pengurus yang memany memunyai keterampilan tertentu (seperti tenaga medis), dan bahkan ada kunjungan dari LKS lain untuk semacam studi banding.

Pihak pemerintah, seperti dinas, melakukan kunjungan, pembinaan, dan evaluasi secara berkala. Tugas-tugas yang biasanya dilakukan pemerintah terhadap LKS seperti penguatan kapasitas pengelolaan/manajemen LKS, mengalokasikan dana APBD untuk membantu biaya operasional pelayanan LKS, dan mendorong LKS untuk mengikuti akreditasi. Kendala dengan pihak pemerintah umumnya yang dialami LKS di Kabupaten Garut adalah persoalan dana operasional atau suntikan dana pemerintah, umumnya dari jadwal pemberian dana tersebut yang dikeluhkan. Dari sisi pihak pemerintah sendiri, ada beberapa LKS yang tidak memberikan laporan penyaluran dan penggunaan dana.

"Proses pemerintah daerah bekerja sama dengan LKS-LKS terutama dalam memberikan dukungan dana adalah melalui langkah-langkah mengidentifikasi LKS-LKS yang layak, selanjutnya LKS mengajukan proposal, lalu proposal yang diverifikasi diajukan dan ditelaah dan jika layak kemudian akan diberikan rekomendasi untuk mendapatkan bantuan dana. [...] Pemerintah pusat berperan menyalurkan dana dekonsentrasi melalui pemerintah daerah. [...] Yang menjadi kendala adalah tidak adanya laporan berkaitan dengan penyaluran dan penggunaan dana yang diberikan. Harapannya adalah mekanisme pelaporan diikuti dan dipatuhi." Kutipan wawancara mendalam dengan Drs. Abu Yaya, M.Si., Kepala Bidang Pemberdayaan Sosial Dinas Sosial Kabupaten Garut

Kemudian, subaspek ketiga, partisipasi dan kelekatan komunitas atau organisasi LKS di Kabupaten Garut, dapat dilihat dari membuka ruang partisipasi, kesamaan kepentingan, kepercayaan, dan bentuk kerja sama yang saling menguntungkan dengan komunitas atau organisasi. Dalam hal ini, komunitas atau organisasi yang dimaksud semisal 
komunitas sosial, komunitas akademis, atau organisasi bisnis. Secara umum bagi LKS di Kabupaten Garut, lebih banyak bekerja sama dengan pihak universitas, seperti kunjungan dosen, pembinaan, mahasiwa praktik, magang, skripsi, dan sejenisnya.

Adapun perusahaan di sekitar belum melakukan pemberdayaan berkelanjutan. Bantuan hanya diberikan berupa charity pada hari-hari perayaan. Dari yang sudah diwawancara, hanya ada satu LKS yang telah bekerja sama dalam bentuk pemberdayaan kreatif dengan perusahaan. Meskipun, berkebalikan dengan situasi yang ada, LKS-LKS sebetulnya menaruh harapan yang besar untuk bisa membina hubungan atau kerja sama yang berkelanjutan dengan perusahaan.

"Kami bekerjasama dengan perusahaan dalam bentuk bakti sosial berupa pemberian bantuan/bingkisan dan kegiatan pemberdayaan kreatif. Dengan organisasi internasional belum pernah. Dengan kampus juga sering sebagai tempat penelitian atau melakukan kunjungan studi. Dengan komunitas sosial atau komunitas kebudayaan ada kerjasama hanya sebatas bakti sosial saja mereka memberikan bingkisan atau bantuan/sumbangan. [...] Hubungan dengan pihak-pihak tadi terjalin dengan baik karena didorong oleh adanya perhatian, kepedulian, dan rasa kemanusiaan ingin membantu anak asuh/yatim." Kutipan wawancara mendalam dengan Ibu Aam Rohamah, Bendahara LKSA AlAmin

"Tidak ada dari perusahaan. Kalau dari universitas ada bimbingan pelatihan dari dokter-dokter. Kalau mahasiswa mau praktik atau tugas atau skripsi ada syarat berbayar. [...] Hubungannya baik, terutama dengan sekolah atau D3 yang medis. [...] (harapannya) Ada dukungan dari pihak lain saja. Perusahaan di sekitar sepertinya belum tertarik dalam penanganan PMKS." Kutipan wawancara mendalam dengan Viera Nirwanti dan Wulan, Tenaga Medis di Yayasan Nurilahie Assani

Subaspek terakhir, partisipasi dan kelekatan kelompok masyarakat, dapat dilihat dari ruang partisipasi dan kepercayaan dari kelompok terkait. Dalam hal ini, kelompok masyarakat terkait yang dimaksud semisal warga sekitar, kelompok pemuda, atau keluarga. Secara umum bagi LKS di Kabupaten Garut, keluarga penghuni berkunjung secara berkala, dan hubungan baik, mereka membantu demi kesejahteraan penghuni.

Tidak ada kerja sama formal dengan warga sekitar seperti kelompok pemuda, PKK, dan sebagainya, kecuali saling berpartisipasi dalam kegiatankegiatan bersama saja. Namun, ada beberapa yang menjadi relawan khususnya 
saat ada hari perayaan. Selain itu, relawan juga hadir dari komunitas masyarakat yang peduli, seperti komunitas masyarakat peduli kesehatan mental atau lansia atau anak.

Kendalanya dalam hal ini adalah kunjungan keluarga di era pandemi seperti ini. Oleh sebab pandemi tersebut, ad batasan-batasan tertentu bagi pihak luar (termasuk keluarga) dalam mengunjungi PMKS di LKS. Padahal, keinginan klien LKS umumnya adalah tetap ingin bertemu dengan keluarga secara rutin meski sedang pandemi. Akhirnya, para pengurus pun harus berkompromi dengan situasi tersebut, seperti lebih berhati-hati apabila ada keluarga yang berkunjung dengan protokol kesehatan serta memberi nasihat kepada klien tentang sulitnya situasi yang ada akibat pandemi dalam mendapat tamu dari pihak luar. Kendalanya dalam hal ini adalah beberapa keluarga kerap kurang mematuhi peraturan-peraturan yang ada di LKS. Namun, kembali lagi, secara umum, keluarga sangat mendukung penyelenggaraan kesejahteraan sosiall di LKS.

"Ya, yang penting ada dukungan saja dan hubungan terus baik dengan keluarga. Kalau masyarakat sekitar, sebagian memang menyekolahkan anaknya di sini kalau memang anakanak mereka berkebutuhan khusus. Masyarakat sekitar sadar keberadaan sekolah ini dan mengapresiasinya, itu saja sudah senang kami." Kutipan wawancara mendalam dengan Ibu
Umi Neni Haryani, Ketua Yayasan

Bina Grahita Leles Garut

\section{Analisis Masalah Tata Kelola LKS di Kabupaten Garut pada Aspek Kolaborasi dan Kemitraan}

Secara umum, kendala dan harapan utama LKS-LKS di Kabupaten Garut dalam pengelolaan kelembagaan adalah terkait pendanaan. Beberapa pengurus LKS-LKS di Kabupaten Garut mengatakan, kendalanya berupa sulitnya mendapatkan bantuan dana dari pihak lain, selain pemerintah. Alhasil, harapannya adalah memperoleh dana lebih yang sumbernya dari banyak pihak, supaya tidak hanya bergantung pada pemerintah atau keluarga atau yayasan yang memang jumlahnya terbatas. Dana ini umumnya digunakan untuk memastikan operasional LKS agar bisa berjalan makin lancar (seperti membeli kendaraan operasional khusus bagi LKS) dan merawat fasilitas sarana-prasarana yang sudah rusak. Beberapa juga menyebutkan dana dimanfaatkan untuk melengkapi alat-alat teknologi yang dapat membantu kesejahteraan klien (seperti kursi roda dan alat bantu dengar untuk lansia, komputer/laptop untuk belajar anak, teknologi medis untuk layanan kesehatan klien, dan sebagainya).

Kemudian, kendala dan harapan utama LKS-LKS di Kabupaten Garut dalam berkolaborasi dan bermitra umumnya adalah terkait kerja sama dengan pihak swasta. Beberapa pengurus 
LKS-LKS di Kabupaten Garut mengatakan, kendalanya berupa sulitnya bekerja sama dengan perusahaan yang sifatnya jangka panjang, umumnya sebatas bersifat charity yang biasanya diberikan saat perayaan hari-hari besar. Alhasil, harapannya adalah membina relasi dengan perusahaan secara berkelanjutan.

Keuntungan kerja sama yang diharapkan oleh LKS-LKS di Kabupaten Garut seperti dana atau barang-barang kebutuhan sehari-hari secara rutin, pemberdayaan atau pelatihan bagi klien dan pengurus, serta pelatihan khusus bagi klien (khususnya pada LKS yang menangani anak-anak) agar ketika klien sudah lulus bisa langsung bekerja di tempat tersebut.

Terakhir, LKS-LKS di Kabupaten Garut mempunyai kelemahan dan kelebihan terkait aktivitas kolaborasi dan kemitraan. Artinya, kelemahan tersebut dapat memperburuk aktivitas kolaborasi dan kemitraan, sedangkan kelebihan tersebut dapat mengoptimalkan aktivitas kolaborasi dan kemitraan. Secara umum, kelemahan LKS-LKS di Kabupaten Garut dalam berkolaborasi dan bermitra ada tiga, yaitu belum maksimal dalam meningkatkan kesadaran dan partisipasi masyarakat umum, belum maksimal dalam mendapatkan kepercayaan dari perusahaan untuk bekerja sama, dan kurangnya kompetensi pengurus.

Ketiga hal tersebut menandakan ada tiga masalah yang perlu diatasi, yakni public awareness, public trust, dan kompetensi public relation. Sementara itu, kelebihan LKS-LKS di Kabupaten Garut dalam berkolaborasi dan bermitra umumnya adalah kuatnya kolaborasi internal dan sudah terbentuknya kerja sama yang cukup baik dengan pihak pemerintah (khususnya daerah), komunitas akademis (pihak universitas), dan komunitas sosial (relawan-relawan yang memang peduli dengan penyelenggaraan kesejahteraan sosial terkait).

\section{Strategi Kapabilitas Relasional: Memperkuat Tata Kelola LKS di Kabupaten Garut pada Aspek Kolaborasi dan Kemitraan}

Strategi kapabilitas relasional adalah rancangan aksi untuk memperkuat kapasitas tata kelola lembaga dalam membangun hubungan berkelanjutan antar pihak internal dan dengan pihak eksternal (Renouard, 2011; Giraud et al., 2013; Bell et al., 2015). Artinya, strategi ini dimaksudkan sebagai upaya penguatan kapasitas tata kelola lembaga pada aspek kolaborasi dan kemitraan. Sebagai konsep yang mandiri, definisi kapabilitas relasional adalah kebebasan nyata, atau terbukanya berbagai pilihan dan kesempatan, bagi individu atau kelompok untuk diinklusikan dalam suatu kolektivitas (Renouard 2011; Giraud et al. 2013).

Konsep ini kentara menitikberatkan pada relasi atau hubungan dan proses sosial; asumsinya adalah 
kebersamaan dan kerja sama mengantarkan kelompok tersebut dan individu-individunya ke keadaan adil dan well-being. Oleh sebab itu, pengaplikasian konsep kapabilitas relasional sebagai strategi kelembagaan, khususnya dalam tata kelola lembaga pada aspek kolaborasi dan kemitraan, menjadi relevan. Kedua hal tersebut sama-sama menekankan pada relasi sosial sebagai sebentuk modal atau sumber daya yang dapat menguntungkan.

Dalam merancang strategi kapabilitas relasional bagi LKS di Kabupaten Garut, perlu dijabarkan lebih dahulu empat hal untuk menetapkan suatu rancangan aksi. Basis penetapan ke-empat hal tersebut adalah kondisi kelembagaan LKS di Kabupaten Garut secara umum dan pada aspek kolaborasi dan kemitraanyang sudah dibahas dan dianalisis pada dua subbab sebelumnya. Empat hal yang dimaksud berupa:

a. Tujuan jangka panjang atau dampak strategi yang ditetapkan berdasarkan "kendala dan harapan utama LKS-LKS di Kabupaten Garut dalam pengelolaan kelembagaan"

b. Tujuan strategi yang ditetapkan berdasarkan "kendala dan harapan utama LKS-LKS di Kabupaten Garut dalam berkolaborasi dan bermitra"

c. Objektif strategi yang ditetapkan berdasarkan "kelemahan-kelemahan yang dimiliki LKS-LKS di Kabupaten Garut yang dapat memperburuk aktivitas kolaborasi dan kemitraan"

d. Inisiatif strategi yang ditetapkan berdasarkan "kelebihan-kelebihan yang dimiliki LKS-LKS di Kabupaten Garut yang dapat mengoptimalkan aktivitas kolaborasi dan kemitraan" 


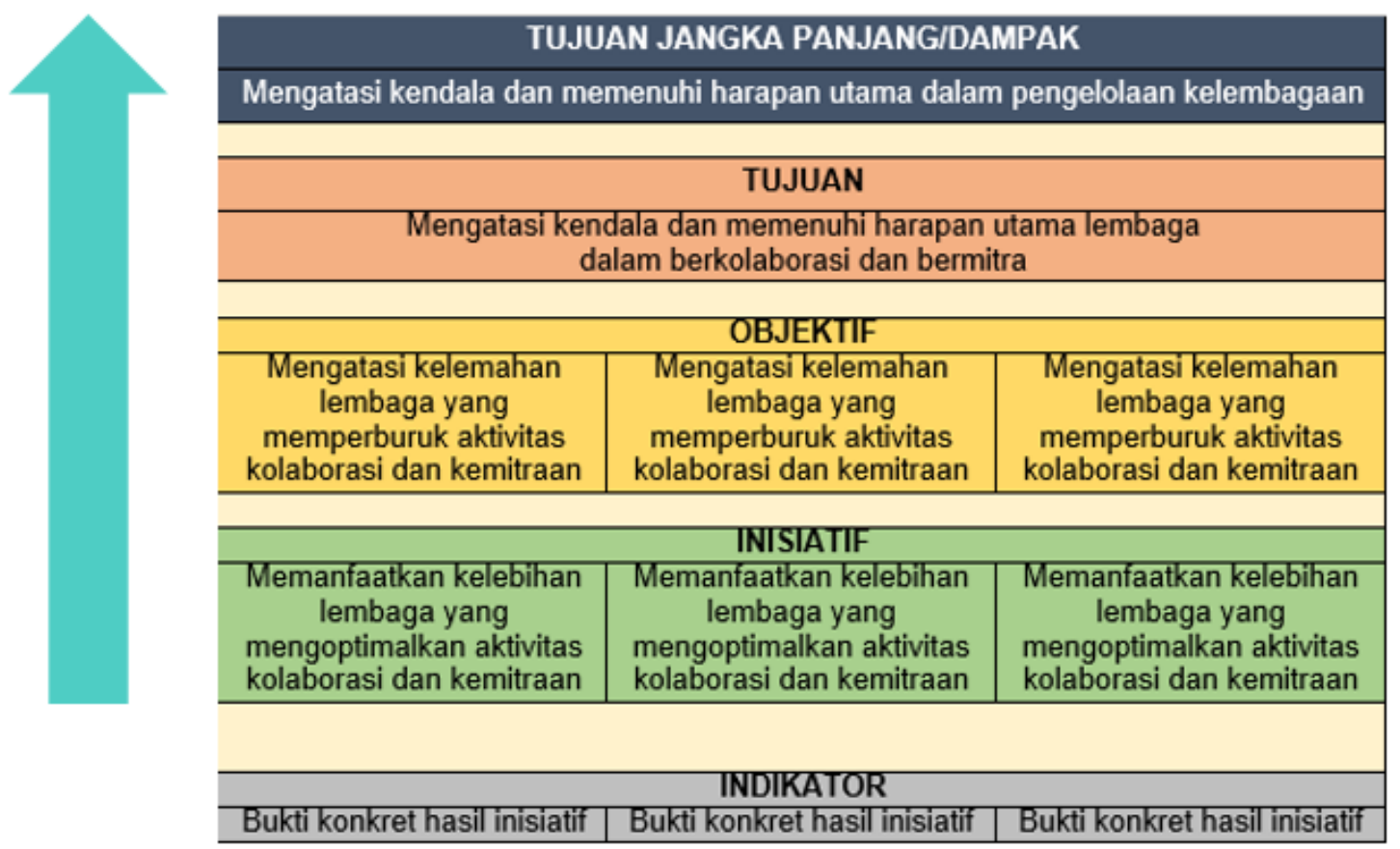

Gambar 1: Alur Rancangan Aksi Strategi Kapabilitas Relasional

Gambar 1 di atas menjelaskan secara skematis bagaimana alur rancangan aksi dalam strategi kapabilitas relasional yang memuat empat hal yang sudah dijelaskan sebelumnya. Alur tersebut mengartikan perlu adanya inisiatif strategi dengan cara "memanfaatkan kelebihan-kelebihan lembaga yang dapat mengoptimalkan aktivitas kolaborasi dan kemitraan", sehingga dapat memenuhi objektif strategi untuk "mengatasi kelemahankelemahan lembaga yang dapat memperburuk aktivitas kolaborasi dan kemitraan". Alhasil, setelah objektif strategi tersebut dapat dipenuhi, tujuan strategi pun dapat tercapai berupa "mengatasi kendala dan memenuhi harapan utama lembaga dalam berkolaborasi dan bermitra".
Akhirnya, dengan sudah terbentuknya aktivitas kolaborasi dan kemitraan yang baik sesuai tujuan strategi, keuntungan ekstra pun dapat diperoleh dalam bentuk tujuan jangka panjang atau dampak yang berupa "mengatasi kendala dan memenuhi harapan utama lembaga dalam pengelolaan kelembagaan".

Dengan demikian, berdasarkan pembahasan di atas, dapat dirancang strategi kapabilitas relasional bagi LKS di Kabupaten Garut sesuai alur rancangan aksi pada Gambar 1. Berikut strategi kapabilitas relasional bagi LKS di Kabupaten Garut yang merupakan "rancangan aksi untuk memperkuat kapasitas tata kelola lembaga dalam membangun hubungan berkelanjutan antar pihak internal dan dengan pihak eksternal 
(Renouard, 2011; Giraud et al., 2013; Bell et al., 2015)" atau "upaya memperkuat kapasitas tata kelola LKS di Kabupaten
Garut pada aspek kolaborasi dan kemitraan":

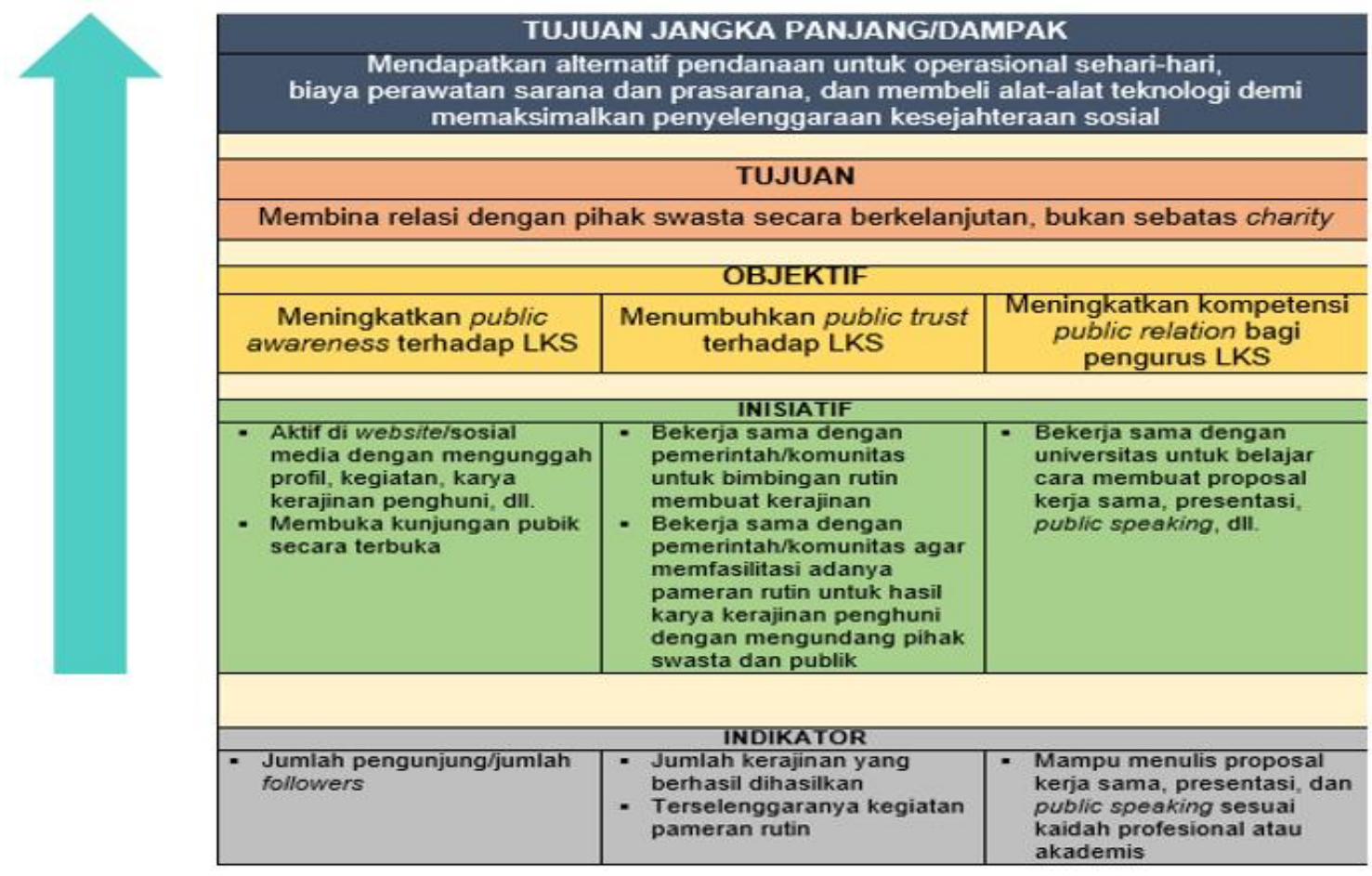

Gambar 2: Strategi Kapabilitas Relasional bagi LKS di Kabupaten Garut

\section{KESIMPULAN}

Strategi kapabilitas relasional tepat untuk diterapkan pada LKS di Kabupaten Garut. Strategi ini memuat rancangan aksi guna memperbaiki kualitas hubungan internal dan eksternal LKS di Kabupaten Garut, sehingga dapat mengoptimalkan kapasitas tata kelola kelembagaannya pada aspek kolaborasi dan kemitraan. Berdasarkan strategi ini, tiga objektif yang patut dicapai oleh LKS di Kabupaten Garut demi memperbaiki kualitas hubungan internal dan eksternalnya adalah meningkatkan public awareness terhadap LKS, menumbuhkan public trust terhadap
LKS, dan meningkatkan kompetensi public relation bagi pengurus LKS.

Jika berhasil dicapai, LKS di Kabupaten Garut dapat mengatasi kendala dan memenuhi harapan utama menyangkut isu hubungan ini, yaitu membina relasi dengan pihak swasta secara berkelanjutan, bukan sebatas charity. Pada akhirnya, bentuk relasi semacam ini bisa berguna sebagai sebentuk modal yang mampu memaksimalkan penyelenggaraan kesejahteraan sosial. LKS di Kabupaten Garut dapat memanfaatkan hal tersebut untuk mengatasi kendala dan memenuhi 
harapan utama dalam pengelolaan kelembagaan, yaitu mendapatkan sumber alternatif pendanaan.

\section{SARAN}

Penelitian ini mempunya dua jenis saran, yaitu praktis dan akademis. Saran praktis adalah usul dari penelitian ini untuk dapat membantu mengimplementasikan program yang ditawarkan penelitian ini. Kemudian, saran akademis adalah usul dari penelitian ini untuk mempertimbangkan penelitian lanjutan yang terkait dengan penelitian ini.

Secara praktis, penelitian ini menyarankan adanya komitmen multiaktor untuk mengimplementasikan strategi kapabilitas relasional. Tidak hanya pemerintah dan LKS, strategi kapabilitas relasional membutuhkan dukungan dari stakeholder lainnya, seperti komunitas akademis, komunitas sosial, pihak media, dan pihak swasta. Salah satu cara untuk membangkitkan komitmen tersebut adalah pemerintah memberikan penghargaan tertentu bagi pihak-pihak yang bersedia berkomitmen.

Kemudian, secara akademis, penelitian ini menyarankan untuk melakukan penelitian lanjutan yang spesifik tentang penguatan kapasitas tata kelola LKS, khususnya mengenai strategi peningkatan kompetensi dan profesionalitas SDM pengurus LKSyang memang ditemukan dalam penelitian ini masih menjadi salah satu kendala utama. Strategi tersebut dapat menggunakan pendekatan yang mereplikasi hasil penelitian-penelitian di luar negeri (luar Indonesia), seperti pendekatan leadership development program dan independent organization.

\section{DAFTAR PUSTAKA}

Austin et al. (2011). Building Managerial and Organizational Capacity in Nonprogit Human Service Organizations Thorugh Leadership Development Program. Administration in Social Work, Vol. 35, No. 3, 258-281.

Bell et al. (2015). Identifying, Defining, and Assesing Child Welfare Organizational Capacities. Virgin Island: Child Welfare Capacity Building Collaborative.

Creswell, J. W. (2003). Research Design: Qualitative, Quantitative, and Mixed Methods Approaches (Second Edition). London: Sage Publications.

Dinsos Jabar. (2018). Dataset Dinas Sosial. Retrieved April 08, 2020, from Jabar Open Data: https://data.jabarprov.go.id/dataset $? \mathrm{q}=$ dinas + sosial

Dinsos Jabar. (2019). Dataset Dinas Sosial. Retrieved April 08, 2020, from Jabar Open Data: https://data.jabarprov.go.id/dataset ?q=dinas + sosial

Dinsos Jabar. (2020). Dataset Dinas Sosial. Retrieved April 08, 2020, from Jabar Open Data: https://data.jabarprov.go.id/dataset $? \mathrm{q}=$ dinas + sosial

Diyanayati, K. (2014). Penyelenggaraan Kesejahteraan Sosial di Daerah Tertinggal: Studi Kasus 
Kabupaten Garut. Jurnal PKS, Vol. 13, No. 4, 343-359.

Giraud et al. (2013). Relational Capability: A Multidimensional Approach. Cergy-Pontoise: Essec Business School.

Kemensos. (2019). Laporan Kinerja Kementerian Sosial RI Tahun 2018. Jakarta: Kementerian Sosial Republik Indonesia.

Kuswanda, D., \& Sundayani, Y. (2013).

Pelayanan Kesejahteraan Sosial Melalui Rumah Sosial Amanah di Keluarahan Muarasanding Kecamatan Garut Kota Kabupaten Garut. Jurnal Ilmiah Pekerjaan Sosial, Vol. 12, No. 1, 1-13.

Marbun et al. (2012). Peran Lembaga Kesejahteraan Sosial (LKS) dalam Penanganan

Penyalahgunaan Napza di Jawa Barat. Jurnal Ilmiah Pekerjaan Sosial, Vol. 11, No. 1, 1-17

Maynard, B. R. (2010). Social Service Organizations in the Era of Evidence-based Practice (The Learning Organization as a Guiding Framework for Bridging Science to Service). Journal of Social Work, Vol. 10, No. 3, 301316.

McPherson, J., \& Abell, N. (2020). Measuring Rights-based Practice (Introducing the Human Rights Methods in Social Work Scales). British Journal of Social Work, Vol. 50, 222-242.

Patras, J., \& Klest, S. K. (2011). Development of a Collective Efficacy Measure for Use in Social Service Organizations. Journal of Social Work, Vol. 13, No. 1, 96-106.

Pikiran Rakyat. (2019, Oktober 16). Hanya Mampu Selesaikan 20
Persen Masalah Sosial, Dinsos Jabar Gandeng Perusahaan Berkolaborasi. Retrieved April 08, 2020, from Pikiran Rakyat: https://www.pikiranrakyat.com/bandung-raya/pr01321192/hanya- mampuselesaikan-20-persen-masalahsosial-dinsos-jabar-gandengperusahaan- berkolaborasi

Renouard, C. (2011). Corporate Social Responsibility, Utilitarianism, and the Capabilities Approach. Journal of Business Ethics, Vol. 98, No. 1, 85-97.

Sitepu, A. (2011). Konstruksi Lembaga Kesejahteraan Sosial untuk Pemberdayaan Masyarakat dalam Rangka Penanggulangan Kemiskinan. Jurnal Penelitian dan Pengembangan Kesejahteraan Sosial, Vol. 16, No. 01, 1-16.

Sugiyanto. (2019). Tipologi Governance Lembaga Kesejahteraan Sosial (LKS): Studi Kasus LKS Mardi Wuto dan LKS Hamba di Daerah Istimewa Yogyakarta. Yogyakarta: Universitas Islam Indonesia.

Turpin et al. (2020). Workload and Wokplace Safety in Social Service Organizations. Journal of Social Work, Vol. 0, No. 0, 1-20.

Williams-Gray, B. (2016). Building Capcity in Nonprofit Human Service Agencies Through Organizational Assessment During the Accreditation Process. Journal of Nonprofit Education and Leadership, Vol. 6, No. 2, 99-114.

Xie et al. (2014). Exploring the Role of Independent Organisations in Care Coordination for Older People in England. Journal of Social Work, Vol. 14, No. 4, 419-438. 